\title{
Trans-Border Movement and Trading Activites across Nigeria- Benin Republic Border
}

\author{
Adetunji Musilimu Adeyinka (PhD) \\ Department of Geography, Faculty of Arts and Social Sciences, \\ Federal University Lokoja, Kogi State, Nigeria \\ Email: maadetunj@yahoo.com, Phone No. +234-8066245425
}

Doi:10.5901/mjss.2014.v5n1p415

\begin{abstract}
In Nigeria and Republic of Benin borders, people move across the boundary without possessing all the necessary documents to back up their journey. It is on this premise that this study examines the salient factors responsible for movement of people across Nigeria - Republic of Benin borders. The study covers three local government areas in Ogun state sharing borders with Republic of Benin. The structured questionnaire was designed to elicit information from the head of household on their involvement in trans-border trading. Secondary data were obtained from the documentary sources. Descriptive and inferential statistics were employed to analyses the data. The finding revealed that people move freely across the borders to visit their friends, engage in social functions and involved in trans-border trading. The study concludes that the Nigerian government should regulate the custom duty imposed on goods imported into the country so as to normalize the differential in the price of goods. Besides, there is need to enlighten the communities border the rationale behind the possession of travelling document before crossing the international boundaries.
\end{abstract}

Keyword: Development, Education, Border, Travel, Trading, Visa.

\section{Introduction}

Movement of people across the international boundaries is a universal phenomenon. This kind of movement can be legal or illegal depending on the circumstances warranting such type of trip. When a national or foreigner passes across an international boundary without having the entire necessary document that back up his trip such movement is regarded as illegal and unconstitutional. In traditional African communities, people see themselves as one. They commute from one community to another to visit their relatives, engage in business transactions, social trips and for safety during political unrest in their home towns. In modern African societies, the political border imposed by the colonial imperialist has created impediments toward free movement of people across the international boundaries and consequently discouraged their relationship with the neighboring countries. This problem has not been properly addressed by some of the researchers on trans-border movement which gives room to smuggling, human trafficking, and stealing, violence and other social vices among the communities' borders (Paul, 2002).

Studies have shown that socio-economic characteristics of households determine to a greater extent their involvement in cross- border movement. A study carried out in 1991 by International Labour Organization in SubSaharan Africa affirms that informal trading constitutes the major source of income for women and serves as means of their financing themselves as well as their wards as the situation demands (ILO, 1991). Similarly, in southern African communities, the number of women participating in informal cross-border trading has increased tremendously and constitutes between 70-80 percent (Makombe, 2011).

It is worrisome to see that many border officers in African countries even encourage illegal trading across the international boundaries. On several occasions, they collect bribes from traders and exploit their ignorance to harass women during their transits (Makombe, 2011). At this juncture, one would find it difficult to say precisely whether it is economic, social or political factor that is responsible for illegal trading across the international boundaries in African countries. It is on these premises that this study examines the principal factors responsible for illegal trading across the international boundaries between Republic of Benin and Nigeria in Ogun State, Nigeria so as to proffer solution to the menace of illegal trading in African countries. 


\section{Study Area}

The study area covers three local government areas in Ogun state. These are Ipokia, Yewa North and Imeko / Afon. One community that shares boundaries with the neighboring country is randomly selected from each local government mentioned above. The major occupation of the people in these communities is arable farming. They cultivate cassava and maize. Also fishing is practiced on Yewa River by some inhabitants of the area to supplement their food crops. The land in these areas is not suitable for cultivation of cash crops like cocoa, rubber, citrus and many economic crops. The stipend earned from farming activities has led the youths to look elsewhere for survival, hence they resorted to illegal businesses like smuggling of rice, used tires, cloths, shoes, jewelries, tinned tomatoes, alcoholic drinks and automobiles.

The transport infrastructure in these communities is extremely poor. The principal means of transport in the area are motorcycles and bicycles. The presence of governments on regional development at local, state and federal levels is rarely felt due to low population density. The thinking of governments on development of border communities is that it is a target for destruction during the time of international war. The Bakassi Peninsula problem that led to some military skirmishes before it was eventually settled at the international level is a typical example. The educational facilities in the areas are not evenly distributed. Many of the secondary school pupils travel long distances to have access to education, while the commuting radius of primary school pupils is shorter in the area. The people in these communities are less accessible to the health facilities. The inadequate access to the social facilities in these areas has aggravated the poverty condition of the people and consequently encourages many of the inhabitants of the areas to travel out of the region. Many petrol stations located in these areas are serving as avenue for transporting petroleum products to the Republic of Benin. It is sometimes difficult to distinguish between the people of Nigeria from those of Republic of Benin due to similarity in culture, languages, mode of dressing and social interaction. The Yoruba people of the study area are related by birth historically. It was the arbitrary partitioning of Africa in general that led to the separation of kits and kins from one another. This is why we have the Katus, Sabes and Popos who are the children of Oduduwa the fore father of the Yoruba of the western part of Nigeria in the Republic of Benin. Any social function in the area of study always influences the areas that are very close to the Republic of Benin because of their interaction with their relatives.

\section{Methodology}

The study covers three local government areas in Ogun state which, share borders with Republic of Benin. These are Ipokia, Yewa North and Imeko / Afon. One community each is randomly selected in the three local government areas. Primary and secondary sources of data are used for the study. In the primary data employed, the structured questionnaire are designed to elicit information from the head of household on their involvement in trans border- trading particularly with regards to possession of travel document, sex, income, reasons for movement and strategies adopted during trips In each of the settlement selected for study, a systematic random sampling technique is employed to select the respondent on the principle of one in every five buildings. In case of many households in a residential building, only one household was selected for questionnaire administration. In all, an average of one hundred and twenty questionnaires is gathered for the analysis and data presentation. Secondary data are obtained from the documentary sources. Descriptive and inferential statistics are employed to analyze the data.

\section{Results and Discussion}

Generally, in African countries and most especially in Nigeria, very few people are engaged in the formal section of the economy. A critical examination of the occupational profile of the respondents in Table 1 reveals that $10.5 \%$ of the respondents indicated that they are public servants. Approximately $38.9 \%$ of the respondents claimed that their primary occupation is artisanship, another $21.1 \%$ of the respondents interacted with indicated that they are traders and another $22.2 \%$ of the respondents indicated that they engaged in trading activities, while $15.8 \%$ and $7.4 \%$ are farmers and transport operators, respectively. It is pertinent to note that more than $60 \%$ of the respondents interacted with who are in the informal sector of the economy claimed that they engaged in trans- border trading to supplement their meager income from their primary occupation.

Table 1: Occupation Profile of Respondents in Communities Border in Nigeria 
Source: Author's Field Work, 2012

\begin{tabular}{ll}
\hline Occupation & Percentage \\
Farming & $15.8 \%$ \\
Artisanship & $38.9 \%$ \\
Public Servant & $10.5 \%$ \\
Trading & $22.2 \%$ \\
Transport Operators & $7.4 \%$ \\
Others & $5.3 \%$ \\
Total & $100.0 \%$ \\
\hline
\end{tabular}

\subsection{Household Income of the Respondents}

In some of the developing countries of the world, the level of poverty is very high, most especially in Nigeria where more than $80 \%$ could hardly eat two meals per day. The situation is endemic in the border communities between Nigeria Benin Republic. For instance, Table 2 shows that an overwhelming (79\%) of the inhabitants of border communities in Nigeria earn less than N40,000 per month. This is an indication of a high level of poverty, particularly in Nigeria where the average household size is between 4 and 5 people (NPC, 2006). This shows that an individual cannot spend an average of $\$ 1.25$ per day as specified by the United Nation for an ideal living standard (World Bank, 2008). Obviously, this observation could be justified on the ground that non- propulsive industry that can generate employment opportunities for the youth in the region is established. As a matter of fact, non- government developmental strategies to enhance regional development could hardly be felt and this might be largely responsible for many of the inhabitants of the area engaging in trans- border trading to earn their livelihood. Further analysis reveals that $13.6 \%$ and $7.4 \%$ of the respondents claimed that they earn between $\# 41,000$ - \#80,000 and above \#81,000. These latter categories of the people were most likely to be the public servants (primary school teachers and nurses in government clinics) and business men in the region.

Table 2: Household Monthly Income in the Border Communities in Nigeria

\begin{tabular}{ll}
\hline Income Group & Percentage \\
Low Income Earners & $79 \%$ \\
Medium Income & $13.6 \%$ \\
High Income & $7.4 \%$ \\
Total & $100.0 \%$ \\
\hline
\end{tabular}

Source: Author's Field Work, 2012

\subsection{Gender of the Trans-border Traders}

At the global level there is gender disparity in the number of people involved in trans- border trading. The situation in African countries is more pronounced due to the fact that women are less employed in the wage paying work. Table 3 reveals that $51.6 \%$ of the respondents are women who claim that they engage in trading activities across the international boundary while $48.4 \%$ of men indicate that they participate in trans- border trading to supplement the income earning from the farming activities in the study area.

Table 3: Gender Participation on Trans border trading

\begin{tabular}{lc}
\hline Gender & Percentage of Gender Involved \\
Male & $48.4 \%$ \\
Female & $51.4 \%$ \\
Total & $100.0 \%$ \\
\hline
\end{tabular}

Source: Author's Field Work, 2013

\subsection{Educational Profile of Respondents}

As a matter of fact, movement across the international boundaries for either business transaction or social trips is 
entertained globally but it becomes illegal when the traveler does not have the entire necessary documents for such trip. Many Nigerians do not possess this legal document for a number of reasons which include the level of illiteracy, awareness and corruption. Table 4 reveals that $33.7 \%$ of the people who claimed that they engaged in trans-border trading do not have formal education. Approximately $35.8 \%$ of the respondents have primary education. A significant proportion of the respondents (21.1\%) claim that they have secondary education.

The result of this analysis actually buttresses the reasons why the majority of the respondents do not bother to have travelling documents before engaging in trans- border trading.

Table 4: Educational Background of the Respondents in Nigeria Border Communities

Source: Author's Field Work, 2012

\begin{tabular}{ll}
\hline Education Background & Percentage(\%) \\
Non-Formal Education & $33.7 \%$ \\
Primary & $35.8 \%$ \\
Secondary & $21.1 \%$ \\
Tertiary & $9.1 \%$ \\
Total & $100.0 \%$ \\
\hline
\end{tabular}

\subsection{Possession of International Passport}

The poor awareness of the relevance of the possession of international passport by many Nigerians who engage in the trading activities' across the international boundaries expose some of them to ridicule, harassment and extortion by the law enforcement agents (border officers) who take the undue advantage to terrorize the travellers. In fact, the result of the analysis on Table 5 indicates that $95.8 \%$ of the respondents who claimed that they engage in trans- border trading do not possess international passport while $4.2 \%$ of the respondents indicated that they have all necessary document before crossing border to engage in their transaction. The result of this observation shows that many of the traders engage in trans- border trading at Nigerian - Republic of Benin border do not possess valid travelling documents as prescribed by the law.

Table 5: Possession of International Passport by Traders across International Boundaries

\begin{tabular}{lc}
\hline International Passport & Percentage of Respondents \\
Yes & $4.2 \%$ \\
No & $95.8 \%$ \\
Total & $100.0 \%$ \\
\hline
\end{tabular}

Source: Author's Field Work, 2012

\subsection{Methods of Movement across the International Boundary in Nigeria-Republic of Benin}

The non-possession of the entire necessary document before crossing international border to engage in trading activities was engendered by border officers who usually shows attitude of indifference after collecting bribe from the travelers. Sometimes, the border communities in Nigeria are more less open markets where the officers at the borders negotiate with the travellers the amount of money to be paid before crossing the international boundary to other countries for their business transactions. The result of the analysis on table 6 reveals that $69.5 \%$ of the respondents who engage in transborder trading in border communities in Nigeria pass through unmanned borders because there are some jungles between Nigeria and Federal Republic of Benin where people can move freely to transact their illegal business. Another $20 \%$ of the travelers claim that they move across the borders with the aid of security personnel who turned themselves to errand officers because of what they intend to benefit from the unscrupulous elements who decide to engage in illegal trading across the international boundaries. Similarly, another $10.6 \%$ of the respondent indicate that they pay their way through the border either because they are well known to them or after tipping the officers at the border. This study therefore affirms that the level of corruption in Nigeria and other African countries is so enormous to the extent that it has negative multiplier effects on the economy of their respective countries. In African countries most especially in Nigeria, it is extremely difficult to know the accurate volume of goods exported or imported into a country due to large number of 
illegal goods moving across the international boundary.

Table 6: Methods of Movement across the International Boundaries in Nigeria

Source: Author's Field Work, 2012

\begin{tabular}{ll}
\hline Methods of Movement & Percentage (\%) \\
With the Aids of Security & $20.0 \%$ \\
Through unmanned border & $69.5 \%$ \\
Pay your way through & $10.5 \%$ \\
Total & $100.0 \%$ \\
\hline
\end{tabular}

\subsection{Modal Choice across the International Border in Nigeria}

Different modes of transport are open to travelers who move across the international border to engage in business transaction. These include, foot, para-transit mode, personal vehicles and aircraft / airplane. However, the circumstances surrounding the types of movement will invariably determine the modal choice of the commuters in Nigeria-Benin Republic borders. Table 7 reveals that $75 \%$ of the traders who passed through unmanned borders claimed that they commute on foot along the jungles to the Republic of Benin. It is interesting to note that many of these traders claimed that they head load the articles or goods along the jungle. No wonder many of them complained of tiredness, headache, back pain and general weakness of body because of the heavy loads they carry on their transits.

Further analysis reveals that many of the traders who move across the jungles which are mostly untarred roads claimed that they depend on unreliable motorcycles to convey their goods, while some of the traders claimed that they occasionally arranged with motor dealers who smuggled fairly used vehicles into the country. Approximately $22.2 \%$ of the travelers who trek across the international boundary with the aid of border officers indicated that they depend on para transit mode to travel to the Benin Republic to transact their business immediately they move across the international boundary. An insignificant proportion (2.8\%) of the trans border traders claimed that they used heavy duty freight vehicle to transport their goods across the Nigeria-Benin border. The last category of these travelers claimed that apart from paying the custom duty for the goods purchased from the Benin Republic, they also have all necessary documents that back up their trips.

Table 7: Modal Choice consideration Across International Boundaries in Nigeria

\begin{tabular}{lc}
\hline Mode & Percentages of Modal Choice \\
Foot $/$ motorcycles & $75 \%$ \\
Taxi/Cab & $22.2 \%$ \\
Heavy Duty Vehicles & $2.8 \%$ \\
\hline
\end{tabular}

Source: Author' Field Work, 2012

\subsection{Articles Purchases across International Boundaries}

African countries are generally the primary producers of agricultural goods and rely on the developed countries for manufactured goods such as automobile, electronics, drugs and many other highly sophisticated goods that require high technological development. It is embarrassing and highly disheartening to see that many Nigerians are still involved in smuggling of consumable goods produced in Benin Republic into the country. Table 8 reveals that $31.6 \%$ of the illegal articles brought to the country are household provisions. Approximately $35.8 \%$ are mainly textiles materials, while $21.1 \%$ of the goods are raw foods such as rice, frozen foods (fish and turkey), fruits and beverages as well as powdered milks. Many of the traders interacted with claim that the price of goods smuggled into the country are relatively cheaper compared to those found in Nigeria due to the high import duties and difference in exchange rates. As a matter of fact, it is glaring from the above observation that the poor implementation policy on international trade that make the price of goods in Nigeria relatively higher than that of Republic of Benin and other African countries has encouraged the smuggling of goods into the country. To confirm this observation, Table 8 further reveals that $11.5 \%$ of the respondents claim that they smuggled automobiles into the country. 
Table 8: Articles purchases across International Boundaries

\begin{tabular}{ll}
\hline Goods Purchases & Percentage (\%) \\
Household provision & $31.6 \%$ \\
Textilematerials & $35.8 \%$ \\
Raw foods & $21.1 \%$ \\
Automobiles & $11.5 \%$ \\
Total & $100.0 \%$ \\
\hline
\end{tabular}

Source: Author's Field Work, 2012

\subsection{Patterns of Development in Border Communities in Nigeria}

Development does not occur simultaneously at the same place, it has to start from somewhere and spread to other places gradually ( Darwent, 1969). No wonder some of the consumable goods such as soft drinks, biscuits, soaps, textile materials produced hundreds of kilometres are still found in the border communities in Nigeria, although, the impact is still small and hardly contributes to the level of development in the region. For security reasons, no government or individual is willing to invest in the border communities because of war.

Although, the three tiers of governments in Nigeria have provided some of the infrastructural facilities (electricity, water and health facilities and schools) to improve the quality of life of their citizenry in the country, the inhabitants of the border communities in Nigeria still benefit a lot from facilities. A critical assessment of the one of basic necessity of life water, in some of the communities along the borders shows that the level of development in the region is still low. For instance, Table 9 reveals that $5.3 \%$ of the respondents depend on stream water, while $49.5 \%$ rely on well water, another $28.4 \%$ claim that they depend on borehole. In all, approximately $83.2 \%$ of these people depend on untreated water which is not safe for drinking. The remaining $16.8 \%$ of the inhabitants claim that they have access to pipe-borne water and in most cases they are likely to be susceptible to water-borne diseases.

Table 9: Sources of Water

Source: Author's Field Work, 2012

\begin{tabular}{lc}
\hline Sources of water & Percentage (\%) \\
Stream & $5.3 \%$ \\
Deep Well & $49.5 \%$ \\
Borehole & $28.4 \%$ \\
Pipe-Borne Water & $16.8 \%$ \\
Total & $100.0 \%$ \\
\hline
\end{tabular}

\subsection{Educational Facilities}

The distribution patterns of educational institutions in border communities in Nigeria also affirm that the level of development is equally low. There is no tertiary institution in the border communities in Nigeria. Many of the children claimed that they commute a considerable distance before they could attend secondary education in the region. For instance, Table 10 reveals that $74.9 \%$ of pupils indicate that they travel less than $1 \mathrm{~km}$ to school, another $17.9 \%$ of the pupils travel between 1 and $5 \mathrm{kms}$ for the same purpose. Approximately $7.3 \%$ of the students commute more than $5 \mathrm{kms}$ to schools. Some of the parents who send their wards to secondary schools located farther away from their villages express dissatisfaction about the school attendance of their children. The distance of the border communities in Nigeria to the higher institutions of learning is worrisome as there is neither privately owned nor public higher institution of learning in the region. The only one tertiary institution that is closer to the border communities in Nigeria- Benin Republic border is Federal Polytechnic llaro which is more than 10 kilometres away from border settlements. 
Table 10: Distance Travel to Education Facilities in Border Communities in Nigeria

\begin{tabular}{ll}
\hline Distances & Percentage (\%) \\
Less than $1 \mathrm{~km}$ & $74.8 \%$ \\
Between $1-5 \mathrm{kms}$ & $17.9 \%$ \\
Above $5 \mathrm{kms}$ & $7.3 \%$ \\
Total & $100.0 \%$ \\
\hline
\end{tabular}

Source: Author's Field Work, 2012

\subsection{Health Facilities in Border Communities in Nigeria}

The provision of health facilities for the inhabitants of community's border is another major concern for all stakeholders in the country. There is no specialist hospital in the border communities in Nigeria. Even where it exits, it is managed by an individual who charges exorbitant fees on the patients. Table 11 reveals that $72.6 \%$ of the inhabitants at the border communities travel for less than $2 \mathrm{~km}$ to attend health care providers in the area. Only less than $8.5 \%$ travel for more than $6 \mathrm{kms}$ for the same purpose.

Table 11: Distance from Residence to Heath Facilities in Border Communities in Nigeria

\begin{tabular}{ll}
\hline Distances & Percentage (\%) \\
Less than $2 \mathrm{kms}$ & $72.6 \%$ \\
Between 2- $4 \mathrm{kms}$ & $5.3 \%$ \\
Between $4-6 \mathrm{kms}$ & $13.7 \%$ \\
More than $6 \mathrm{kms}$ & $8.5 \%$ \\
Total & $100.0 \%$ \\
\hline
\end{tabular}

Source: Author's Field Survey, 2012

\subsection{Factor Analysis}

Obviously, many factors are responsible for trans-border movement and these ranges from demographic factors to political and the patterns of development of the areas. The factor analysis has been employed to determine the principal explanatory variable that influences the pattern of movement across the international boundaries. The result of the analysis on Table 12 reveals that six factors whose Eigen value is greater than one accounts for about $60.8 \%$ of the total variance. Table 11 reveals that the variables loaded on factor 1 are travel characteristics such as (Distance travel $=0.77$ and Modal Choice $=0.67$ ). This accounts for about $13.58 \%$ of the total variance. This could be attributed to the fact that many of the communities along the borders in Nigeria are connected with jungles which makes it easy for travellers to move to the neighbouring country without necessarily passing the border officers. Similarly, the second factor which has $11.63 \%$ of the total variance equally have their variables loaded on transport patterns (Distance secondary school $=0.70$ and Distance to Primary school $=0.69$ ). Factor 3 accounts for $9.63 \%$ of the total variance of the factor responsible for trans-border trading along Nigeria- Republic of Benin. The variable loaded on factor 3 are household or demographic characteristics (Gender $=0.67$ and Household size $=0.53$ ). The study affirms that the gender characteristics of the sampled populations determines to the greater extent the category of people involved in trans- border trading. The number of people in the household also affects the volume of the people moving across the border. Factor 3 has a negative value on (Education level $=-0.64$ and monthly $=-0.22$ ) variables loaded as parts of the factors affecting transborder trading and this accounts for $9.06 \%$ of the total variance. On the other hand, factor 4 accounts for $8.24 \%$ of the total variance of the factor influencing trans-border trading in the study area. The occupation of the household is the major component matrix of variables loaded on factor 4 (Occupation $=0.54$ ). An examination of Figure 2 shows that the screen plot is sharper at point four which is an indication that these four factors earlier discussed are the prominent factors affecting trans-border trading in the study area. Table 12 reveals that other two factors which influence transborder trading are equally demographic characteristics and households travel patterns which accounts for $8.50 \%$ and $8.19 \%$ of variance respectively. Similarly, variables loaded on component matrix are Marital Status (0.51) and Distance Travel to tertiary institution (0.57) respectively. 
Table 12: Results of Factor Analysis on Reasons for Engaging in Trading Activities across the International Boundary.

Total Variance Explained ${ }^{\mathrm{a}}$

\begin{tabular}{|c|c|c|c|c|c|c|c|c|c|}
\hline \multirow[t]{2}{*}{ Component } & \multicolumn{3}{|c|}{ Initial Eigenvalues } & \multicolumn{3}{|c|}{ Extraction Sums of Squared Loadings } & \multicolumn{3}{|c|}{ Rotation Sums of Squared Loadings } \\
\hline & Total & 90 of Variance & Cumulative $\%$ & Total & Qo of Variance & Cumulative $\%$ & Total & 90 of Variance & Cumulative $\%$ \\
\hline 1 & 2.369 & 14.809 & 14.809 & 2.369 & 14.809 & 14.809 & 2.174 & 13.585 & 13.585 \\
\hline 2 & 2.079 & 12.993 & 27.803 & 2.079 & 12.993 & 27.803 & 1.806 & 11.627 & 25.212 \\
\hline 3 & 1.505 & 9.405 & 37.208 & 1.505 & 9.405 & 37.208 & 1.540 & 9.626 & 34.837 \\
\hline 4 & 1.318 & 8.237 & 45.445 & 1.318 & 8.237 & 45.445 & 1.449 & 9.057 & 43.894 \\
\hline 5 & 1.276 & 7.974 & 53.419 & 1.276 & 7.974 & 53.419 & 1.360 & 8.502 & 52.396 \\
\hline 6 & 1.146 & 7.162 & 60.581 & 1.146 & 7.162 & 60.581 & 1.310 & 8.185 & 60.581 \\
\hline 7 & .947 & 5.923 & 66.504 & & & & & & \\
\hline 8 & .878 & 5.485 & 71.989 & & & & & & \\
\hline 9 & .845 & 5.281 & 77.270 & & & & & & \\
\hline 10 & .730 & 4.562 & 81.831 & & & & & & \\
\hline 11 & .679 & 4.246 & 86.077 & & & & & & \\
\hline 12. & 607 & 3.794 & 89.871 & & & & & & \\
\hline 13 & .523 & 3.270 & 93.141 & & & & & & \\
\hline 14 & .464 & 2.898 & 96.039 & & & & & & \\
\hline 15 & .408 & 2.550 & 98.589 & & & & & & \\
\hline 16 & .226 & 1.411 & 100.000 & & & & & & \\
\hline
\end{tabular}

Extraction Method: Principal Component Analysis.

Source: Author's Computation

a. Only cases for which Do you engage in cross border movement $=$ Yes are used in the analysis phase.

Figure 2: The Screen Plot of Factor Analysis

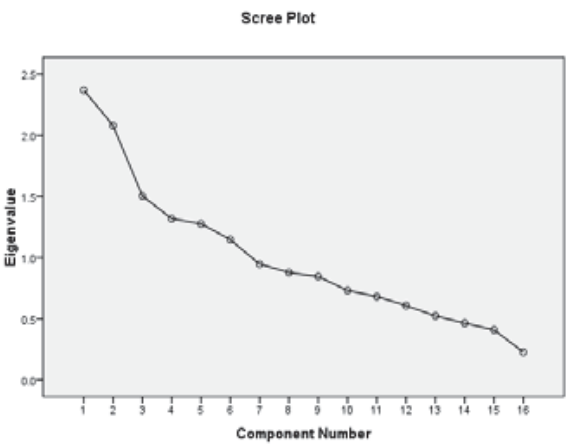

Table 13: Results of Component Matrix on trans border trading

\section{Component Matrix ${ }^{\mathrm{a}, \mathrm{b}}$}

Variables

Ageof Hous ehold Head

Sex

Educational Status

Marital status

Occupation

Monthly income

Distance to water source

Distance to nearest primary school

Distance to nearest secondary school

Distance to tertiary institution

Distance to place of work

Mode of Transportation to work

Mode of Transportation to School

Mode of transportation to Health C entre

Mode of Transportation During vis itation

Extraction Method: Principal Component Analysis

Source: Author's Computation

\begin{tabular}{clllll}
\multicolumn{7}{c}{ Component } \\
$\mathbf{1}$ & $\mathbf{2}$ & $\mathbf{3}$ & $\mathbf{4}$ & $\mathbf{5}$ & $\mathbf{6}$ \\
.491 & -.150 & .240 & -.396 & -.128 & .185 \\
-.299 & -.112 & .670 & .068 & 0.60 & -.248 \\
.103 & .351 & -.643 & .227 & -.022 & -.136 \\
.038 & -.177 & .156 & -.620 & .508 & -.301 \\
.039 & -.310 & .116 & .584 & -.010 & -.193 \\
.505 & .046 & -223 & -.279 & .062 & -.157 \\
.196 & .375 & .530 & .134 & -.431 & -.002 \\
.067 & .493 & -.028 & .069 & .541 & .075 \\
.362 & .694 & .056 & .106 & .331 & -.046 \\
.240 & .700 & .363 & .135 & .098 & .011 \\
.423 & .024 & .020 & .018 & -.037 & .582 \\
.777 & -.152 & .138 & -.019 & -.010 & -.052 \\
.673 & -.257 & .006 & .148 & -.046 & -.223 \\
.144 & -.384 & .127 & .407 & .473 & -.191 \\
.402 & -.425 & -.074 & .247 & .264 & .341 \\
-.348 & -.136 & .203 & .030 & .314 & .573 \\
\hline
\end{tabular}




\section{Conclusions and Recommendations}

This paper assesses the movement of people across the international boundary in Nigeria - Republic of Benin borders. The study has demonstrated that people in African communities sees themselves as one and movements across the international boundaries within African countries should not be strictly restricted because such boundaries were imposed by colonial masters. There is free movement of people across the international boundary to visit their relatives and engage in trading activities. Many of the respondents are of the opinion that the price of goods is relatively cheaper at the Republic of Benin compared to Nigeria. The result of analysis further reveals that the Nigeria borders at Idi-iroko, Beebe, Ohunbe and masny others at Ogun state in Nigeria are too porous to the extent that people move across the international boundary at will after paying their way to border officers. This paper advocates that community's border should be enlightened on the rationale behind the possession of the entire necessary document before moving across the international boundary. The price of automobiles and many other consumable goods smuggled into Nigeria by the itinerant traders / smugglers should not be higher than that of Republic of Benin.

\section{References}

African Union (2007): United Nations Economic Commission for Africa (UNECA) Accelerating Africa's developing through diversification, Ethiopia: AU/ UNECA.

Darwent, D. (1969): "Growth Pole and Growth Centres in Regional Planning - a review," Environment and Planning, Vol. 1 (1969) pp. 5 - 32. Available on line w.w.w.sjsu.edu/faculty/waticins

Deepak,N (2000): Cross Border Movements of People. United Nations. University World Institute for Development of Economic Research. Working Paper No. 194.

International Labour Organization (1991): The Dilemma of the Informal Sector. Report of the Director General, Geneva: ILO.

Makombe, P. F (2011): Cross Border Testimonies, Cape Town. Economic Justice Network, page 3; http://www.trademarksa.org_2011.pdf

National Population Census (2006): National Population Census of the Federal Republic of Nigeria Abuja National Population Commission.

Obanya, P (2010): Planning and Managing Meaningful Access to Education: The Nigerian experience. Centre for International Education University of Sussex. Department of Education opens Seminal Series, 2010.

Paul Nugent (2002): Smugglers, Secessionists, and Loyal Citizens in the Ghana- Togo Frontier.The Lie of Borderlands since 1914. Oxford: James Curry Publishers, Anthens: Ohio University Press, Legion: Sub-Saharan Books, 2002. Pp 302

UNIFEM (2010): Women in Informal Cross Border Trade in Southern Africa, Johannesburg. UNIFEM.

World Bank (2008): Poverty around the World. Available on www.globalissues.org/article/4/poverty-around the-world. 
